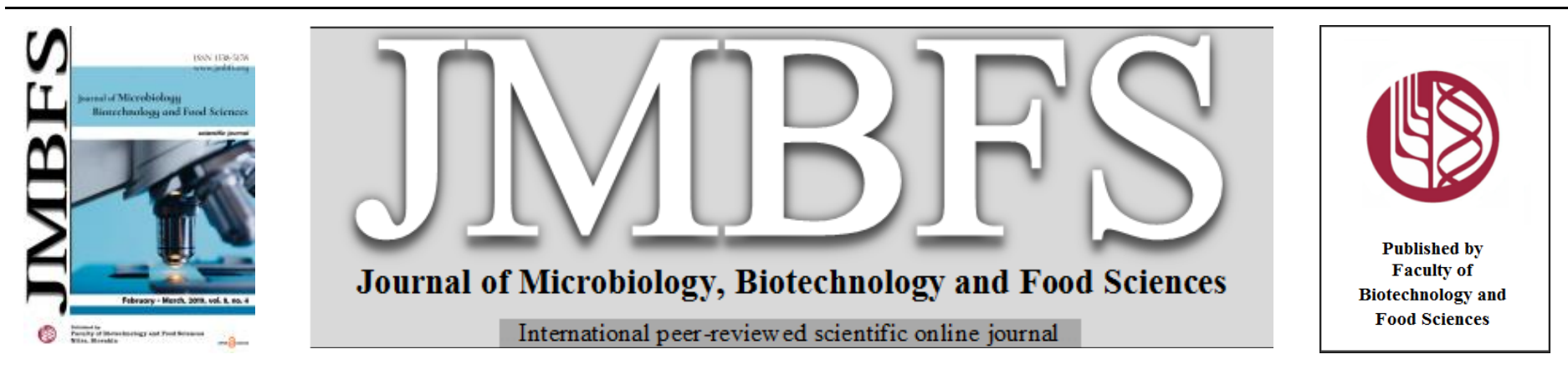

\title{
POTENTIAL EFFECT OF ANTAGONISTIC BACTERIA IN THE MANAGEMENT OF OLIVE KNOT DISEASE CAUSED BY PSEUDOMONAS SAVASTANOI PV. SAVASTANOI
}

\author{
Abdelaaziz Bouaichi ${ }^{1.2 *}$, Rachid Benkirane ${ }^{2}$, Said El-kinany ${ }^{3}$, Khaoula Habbadi ${ }^{2}$, Hanane Lougraimzi ${ }^{4}$, Soumia Sadik ${ }^{5}$, Abdellatif \\ Benbouazzal, El Hassan Achbani ${ }^{l}$
}

Address(es):

${ }^{1}$ National Institute of Agronomic Research, Laboratory of Phytobacteriology and Biocontrol, Meknes, km 13, Route Haj Kaddour, BP. 578 VN 50000 , Morocco. Tel: +212 5 35300366, Fax: +212 5 300244, E-Mail: crrameknes@inra.org.ma.

${ }^{2}$ Ibn Tofial University, Faculty of Science, Laboratory of Botany, Biotechnology and Plant Protection, Kenitra, Morocco.

${ }^{3}$ Sidi Mohamed Ben Abdellah University, Faculty of Sciences and Techniques, Laboratory of microbial biotechnology, Fez, Morocco.

${ }^{4}$ Ibn Tofail University, Faculty of Sciences, Laboratory of Health, Nutrition and Environment, Kenitra, Morocco.

${ }^{5}$ Moulay Ismail University, Faculty of Sciences, Laboratory of Plant Biotechnology and Molecular Biology, Meknes, Morocco.

*Corresponding author: bouaichi.inra@gmail.com

doi: 10.15414/jmbfs.2019.8.4.1035-1040

ARTICLE INFO

Received 10. 3. 2018

Revised 5. 11. 2018

Accepted 7. 11. 2018

Published 1. 2. 2019

Regular article

OPEN $\partial_{\text {ACCESS }}$

\begin{abstract}
Olive knot disease caused by Pseudomonas savastanoi pv. savastanoi (PSS) is considered as the main bacterial disease of olive tree in Morocco. However, sole prophylactic measures are available. The main aim of this work was to evaluate the effects of eighteen antagonistic bacteria, as an alternative approach, to control in vitro and in planta the pathogens strains previously isolated from olive trees in Morocco. In vitro experiments revealed that many bacterial strains such as Rahnella aquatilis, Enterobacter ludwiqii, Paenibacillus brasiliensis, and Bacillus subtilis selected from collection of Regional Center of Agronomic Research, were efficient on solid media against pathogen strains. Their inhibition zones ranged from 8 to $23 \mathrm{~mm}$ with a higher inhibition rates found by $B$. subtilis strains. Enzymatic activities of antagonistic strains were assessed (cellulase, protease and amylase) as well as some plant growth promotion traits (phosphorus solubilisation and indole acetic acid production) for performance screening. B. subtilis 2515-1 was selected for pots experiment using olive trees (cv. Arbequina). This bacterium significantly reduced number and weight of knots against two pathogens strains (PSS 2064-8 and PSS 2102-4). The most reduction rates of weight and knot number were respectively $95.60 \%$ and $50 \%$. This study suggested an alternative approach to assess the efficiency of selected bacterium in field conditions.
\end{abstract}

Keywords: Pseudomonas savastanoi pv. savastanoi, olive knot disease, biological control, antagonistic bacteria, Bacillus subtilis

\section{INTRODUCTION}

Olive knot, caused by the bacterium Pseudomonas savastanoi pv. savastanoi (PSS) is a common and a limiting disease in many olive-producing areas (Young, 2004). The disease is manifested by the production of tumorous woody outgrowths, $2-10 \mathrm{~cm}$ in diameter, that are mostly formed on young stems as well as on branches and twigs. The leaves and fruits are rarely infected, but they usually harbour the bacteria on the surface as residents (Sisto et al., 2004). Olive knot disease is considered an important problem for olive crops because of its effect on vegetative growth (decline of branch and shoots, death of small branches and twigs), olive yield, and even possibly on olive oil quality through inferior organoleptic characteristics such as an unpleasant smell and a bitter, rancid taste (Godena et al., 2012). The better characterized virulence factors in tumor-inducing isolates of $P$. savastanoi pv. savastanoi are the phytohormones indole acetic acid (IAA) and cytokinins (Surico et al., 1985).

Many saprophytic bacteria such as Pseudomonas spp., Pantoea agglomerans, Bacillus subtilis, were used in agriculture as biocontrol agents to control several diseases caused by bacteria and fungi (Mercier and Lindow, 2001; Van den Broek et al., 2003). P. agglomerans which is often associated with olive and oleander knots (Fernandes and Marcelo, 2000; bouaichi et al., 2015) is also used as a biocontrol agent toward different plant diseases (Trotel- Aziz et al., 2008; Sadik et al., 2016). However, it may contribute in knot formation by IAA production (Marchi et al., 2006).

In this study, we aimed to: 1) assess in vitro efficiency of 18 antagonistic bacteria as biocontrol agents against two Pseudomonas savastanoi pv. savastanois strains, causal agents of olive knot in Morocco; 2) investigate theirs mechanisms on solid media such as protease, cellulase and amylase activities as well as siderophores and IAA production, 3) conduct in planta experiment under greenhouse, then confirm this antagonistic activity of selected bacterium (Bacillus subtilis (2515-1) as effective biocontrol agent against PSS 2102-4 and PSS 2064-8 virulent strains of Pseudomonas savastavoi pv. savastanoi (PSS).

\section{MATERIAL AND METHODS}

\section{Inoculum Preparation}

Two strains of Pseudomonas savastanoi pv. savastanoi (PSS 2102-4 and PSS 2064-8) were used in this study, isolated from knot of symptomatic trees in Meknes and Taounat (Morocco) and sub-cultured on King B medium $(20 \mathrm{~g}$ proteose peptone; $1.5 \mathrm{~g} \mathrm{MgSO}_{4} ; 1.5 \mathrm{~g} \mathrm{~K}_{2} \mathrm{HPO}_{4} ; 10 \mathrm{ml}$ glycerol; $20 \mathrm{~g}$ agar; distilled water to 1.0 liter) (King et al., 1954). Bacteria were inoculated on media using inundation method from preserved strains. After incubation for $48 \mathrm{~h}$, suspensions were prepared aseptically in sterile distilled water and their concentrations were adjusted $\left(10^{8} \mathrm{CFU} / \mathrm{ml}\right.$ ) by spectrophotometer (UV-mini 1240, Shimadzu) at $600 \mathrm{~nm}$ (El-kinany et al., 2017).

\section{Antagonistic strains}

All antagonistic strains belong to the collection of laboratory of plant bacteriology and Biological Control at the National Institute of Agronomic Research (Meknes, Morocco). Theirs origins, isolation dates, and references are described in Tab 1. 
Table 1 Antagonistic strains examined for biocontrol efficiency against olive knot

\begin{tabular}{|c|c|c|c|c|}
\hline Codes of strains & Sampling locations & Origin & Species & Gene Bank accession No. \\
\hline Ach2-1 & Meknes & apple & Aureobasidium pullulans, & $*$ \\
\hline $2627-1$ & Meknes & Apple tree & Acinetobacter calcoaceticus & KP170504.1 \\
\hline 2066-7 & Taounat & Olive tree & Pantoeaagglomerans & KJ781904.1 \\
\hline 2077-5 & Meknes & Olive tree & ND & ND \\
\hline 2083-2 & Meknes & Olive tree & ND & ND \\
\hline 2015-1,2027-1,2027-2 & Meknes & Compost & Bacillus cereus & KR493006.1 \\
\hline 2021-12 & Meknes & Compost & Acinetobacter venetianus & KP009554.1 \\
\hline $2510-8$ & Meknes & Olive tree & Pantoea sp. & HQ396801.1 \\
\hline $2510-9$ & Meknes & Olive tree & Pantoea ananatis & KM977993.1 \\
\hline 2332-A & Meknes & Apple tree & Rahnella aquatilis & KM241863.1 \\
\hline 2328-B5 & $\mathrm{Fez}$ & Apple tree & Acinetobacter calcoaceticus & KP170504.1 \\
\hline $2546-4$ & Meknes & Strawberry & Enterobacter ludwiqii & LC015543.1 \\
\hline \multirow{2}{*}{$\begin{array}{l}2025-11 \\
2515-1,2515-2,2515- \\
3\end{array}$} & Meknes & Compost & Paenibacillu sbrasiliensis & $*$ \\
\hline & Meknes & Apple tree & Bacillus subtilis & KJ592619.2 \\
\hline
\end{tabular}

\section{In vitro antagonism}

In vitro antagonism to evaluate the effects of the 18 antagonistic strains agains PSS 2102-4 was carried out using disk agar diffusion method (Habbadi et al. 2017). Briefly, the bacterial suspension of PSS 2102-4 strain with a cell density of $10^{8} \mathrm{CFU} / \mathrm{ml}$ was prepared and spread on YPGA medium $(5 \mathrm{~g}$ yeast extract; $5 \mathrm{~g}$ bacto peptone; $10 \mathrm{~g}$ glucose; $20 \mathrm{~g}$ agar; distilled water to 1 liter). Excess of suspension was eliminated and the Petri dishes were dried aseptically for $15 \mathrm{~min}$ disks of paper containing fresh antagonistic strains were placed on Petri dishes and incubated at $25^{\circ} \mathrm{C}$ for $24 \mathrm{~h}$. Streptomycin was involved as a positive control to compare its effect with bio-agents. The Antagonistic activity was indicated by a clear zone of inhibition around the antagonistic strains. All halo diameters were expressed in millimeters to compare the performance of these antagonists.

\section{Production of enzymes and secondary metabolites}

\section{Phosphorus solubilization}

The phosphorus-solubilizing activity of the antagonistic strains was assessed on Pikovskaya (PVK) medium (Pikovskaya, 1948) which contains $10 \mathrm{~g}$ glucose; $5 \mathrm{~g}$

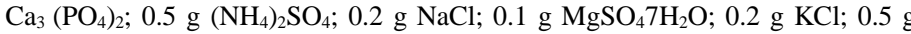
yeast extract; $0.002 \mathrm{~g} \mathrm{MnSO}_{4} \mathrm{H}_{2} \mathrm{O}$; and $0.002 \mathrm{~g} \mathrm{FeSO}_{4} 7 \mathrm{H}_{2} \mathrm{O}, 15 \mathrm{~g}$ agar; distilled water to 1 liter). Inoculated plates, by spot method (Boudyach et al., 2001) were incubated at $27^{\circ} \mathrm{C}$ for 7 days and observed for halo formation. The development of a clear zone around the spot indicates the effectiveness of bacterial antagonist. The solubilization index (SI) of such antagonists was calculated using the formula of Premono et al., (1996): SI = (colony diameter + Halo zone diameter))/colony diameter.

\section{Siderophores production}

Universal method for siderophores production using CAS medium was carried out (Schwyn and Neilands, 1987), although only as a means to reveal changes, without the presence of nutrients. The medium for one Liter of overlay was as follows: Chrome azurol $\mathrm{S}$ (CAS) $60.5 \mathrm{mg}$, hexadecyltrimetyl ammonium bromide (HDTMA) $72.9 \mathrm{mg}$, Piperazine-1, 4-bis (2-ethanesulfonic acid) (PIPES) $30.24 \mathrm{~g}$, and $1 \mathrm{mM} \mathrm{FeCl}{ }_{3} \cdot 6 \mathrm{H} 2 \mathrm{O}$ in $10 \mathrm{mM} \mathrm{HCl} 10 \mathrm{~mL}$. Agarose $(0.9 \%$, w/v) was used as gelling agent.

Overlays of this medium were applied over agar plates containing cultivated strains to be tested for siderophore production. After a maximum period of 15 min, colour changes was observed in the overlaid medium, exclusively surrounding producer strains, from blue to purple (siderophores of the catechol type) or from blue to orange (siderophores of the hydroxamates type). Colony diameter and halo formation were each measured after $1 \mathrm{~h}$ (Schwyn and Neilands, 1987).

\section{Indole Acetic Acid Production}

Production of IAA was tested on Czapek medium (Tsavkelova et al., 2007) containing 20g Glucose; $1 \mathrm{~g} \mathrm{~K}_{2} \mathrm{HPO}_{4} ; 0.5 \mathrm{~g} \mathrm{MgSO}$; 0.5 g yeast extract; 0.1 $\mathrm{NaNO}_{3} ; 0.5 \mathrm{~g} \mathrm{FeSO}_{4} ; 20 \mu \mathrm{l}$. Freshly grown cultures were inoculated into $10 \mathrm{~m}$ Czapek medium to which tryptophan had been added $(1 \mathrm{~g} / \mathrm{L})$ in each test tube and incubated at $30^{\circ} \mathrm{C}$ for $72 \mathrm{~h} .4 \mathrm{ml}$ of culture was removed from each test tube and centrifuged at $10.000 \mathrm{r} / \mathrm{min}$ for $15 \mathrm{~min}$. An aliquot of $1 \mathrm{ml}$ of supernatant was added to $2 \mathrm{ml}$ of Salkowski reagent comprising of ( $1 \mathrm{ml}$ of $0.5 \mathrm{M} \mathrm{FeCl}_{3}$ in $50 \mathrm{~m}$ of $35 \% \mathrm{HCIO}_{4}$ ). The mixture was incubated at room temperature for 25 minutes. The absorbance of the pink solution from each isolate was measured and recorded at $530 \mathrm{~nm}$ using spectrophotometer (Tsavkelova et al., 2007).

\section{Cellulase activity}

Antagonistic bacteria were cultured on CMC plate $\left(0.001 \% \mathrm{MgSO}_{4}, 0.005 \%\right.$ $\mathrm{KH}_{2} \mathrm{PO}_{4}, 0.001 \% \mathrm{CaCl}_{2}, 0.6 \% \mathrm{NaCl}, 0.2 \%\left(\mathrm{NH}_{4}\right)_{2} \mathrm{SO}_{4}, 0.2 \% \mathrm{~K}_{2} \mathrm{HPO}_{4}, 0.1 \%$ yeast extract, $0.5 \% \mathrm{CMC}$ and $1.5 \%$ agar in 1 Liter of distilled water. After growth at $28^{\circ} \mathrm{C}$ for $14 \mathrm{~h}$, cellulase activity of the strains was assayed by checking their ability to form halos detected by Congo red staining (Lin et al., 2009).

\section{Lipase, Protease and $\alpha$-amylase activities}

Extracellular lipase-producing microorganisms were evaluated on differential medium containing; olive oil $20 \mathrm{ml}$, peptone $3 \mathrm{~g}$, yeast extract $2 \mathrm{~g}, \mathrm{~K}_{2} \mathrm{HPO}_{4} 2 \mathrm{~g}$, $\mathrm{MgSO}_{4} 1 \mathrm{~g}, \mathrm{Na}_{2} \mathrm{CO}_{3} 1 \mathrm{~g}$, agar $20 \mathrm{~g}$, and rhodamine B $0.01 \mathrm{~g}$ in 1 Liter of distilled water (Lin et al., 2009). Extracellular protease production was carried out using specific medium containing; $5 \mathrm{~g}$ meat peptone; $3 \mathrm{~g}$ yeast extract; $10 \mathrm{~g}$ skimmed milk powder; and $12 \mathrm{~g}$ agar in 1 liter of distilled water. Finally, on the same medium exempt the skimmed milk, where was substituted by cassava starch, extracellular amylase production was detected (Sharma and Singh, 2015).

All cultures were incubated at $30^{\circ} \mathrm{C}$ for $72 \mathrm{~h}$. If the inoculated bacterium secretes these enzymes, a clear zone of hydrolysis is observed around the inoculant. The relative protease, amylase and lipase activities were calculated by the given formula (Sharma and Singh, 2015):

Relative activity $=\frac{\text { halo zone diameter }}{\text { colony diameter }}$

\section{Effect of $B$. subtilis (2515-1) on olive knot disease}

Greenhouse experiments were performed to determine the effect of B. subtilis (2515-1) on the development of olive knots. One-year-old olive plants (cv. Arbequina) were used. Inoculation method was performed as following (krid $\boldsymbol{e t}$ al., 2012): bacterial suspensions of the pathogen strains (PSS 2102-4 and PSS 2064-8) were prepared in sterile distilled water (SDW) and adjusted at $10^{8}$ $\mathrm{CFU} / \mathrm{ml}$. Each pathogen strain was mixed with the antagonistic bacterium 2515-1 at $10^{8} \mathrm{CFU} / \mathrm{ml}(1: 1 \mathrm{v} / \mathrm{v})$ or with copper sulphate $(0.5 \%)$ for positive control (control plant with chemical treatment). The mixtures were inoculated on the stem using spreading method on eight $\mathrm{V}$ shaped slits (about $1 \mathrm{~mm}$ deep by $3 \mathrm{~mm}$ wide). Slits were covered with Parafilm M. Three plants used for each treatment and eight inoculated wounds. Inoculated plants were kept in a greenhouse at $25^{\circ} \mathrm{C}$. After two months, overgrowths were excised and weighted for comparison between control plants and treated plants. Disease reduction was estimated using the formula (krid et al., 2012):

Disease incidence $=\frac{\text { number of slits with knot }}{\text { number of inoculated slits }} \times 100$

Disease reduction $=\frac{\text { incidence in control plants-incidence in treated plants }}{\text { incidence of control plants }} \times 100$ 


\section{Statistical analysis}

Data were subjected to analysis of variance using SPSS software (version 21; http://www.spss.com). Means of values among the treatments were compared by Dunnett multiple test at the 5\% $(\mathrm{P}=0.05)$ level of significance.

\section{RESULTS AND DISCUSSION}

\section{In vitro antagonism tests}

Eighteen antagonists limited the growth of pathogen strain PSS 2102-4. Results described in Figures $(1 ; 2)$ showed that B. subtilis strain $(2515-1)$ was the most effective bacterium with a higher inhibition zone of $23 \mathrm{~mm}$ which was near to streptomycin effect (positive control) (Figure 2) For the other antagonistic strains, the halo diameters ranged from 8 to $21 \mathrm{~mm}$. B. subtilis strains (2515-2 and 2515-3) did not exert the similar antagonistic effect. Their corresponding diameters were 21 and $20 \mathrm{~mm}$ respectively. E. ludwiqii (2546-4) had an inhibition zone of $21 \mathrm{~mm}$ against PSS 2102-4 (Figure 2). However, R. aquatilis (2332-A) did not exceed 20 mm against PSS 2102-4 (Figure 2). The other strains have showed an inhibition zones less than $20 \mathrm{~mm}$.

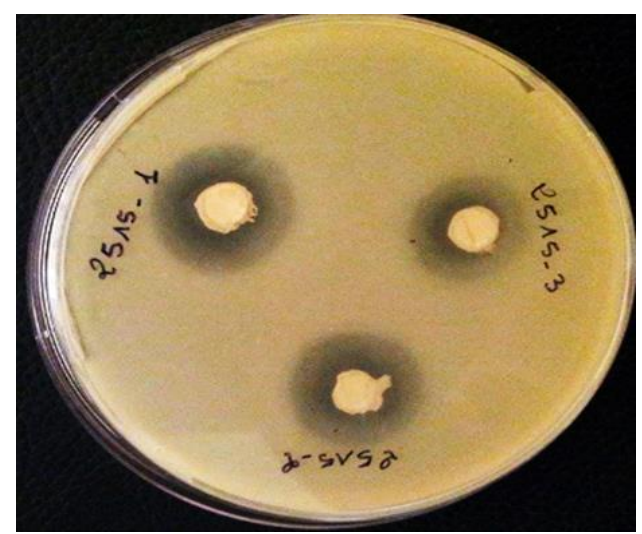

Figure 1 Antagonistic activity of Bacillus subtilis (2515-1, 2515-2 and 2515-3) strains against the Pseudomonas savastanoi pv. savastanoi 2102-4.

Table 2 Production of Enzymes and secondary metabolites by antagonistic strains

\begin{tabular}{|c|c|c|c|c|c|c|c|}
\hline Strains antagonistic & $\begin{array}{c}\text { Phosphate } \\
\text { Solubilization } \\
\text { Index (SI) } \\
\end{array}$ & $\begin{array}{c}\text { siderophore } \\
\text { production } \\
(\mathrm{H} / \mathrm{C})\end{array}$ & $\begin{array}{l}\text { Concentration } \\
\text { IAA }(\mu \mathrm{g} / \mathrm{ml})\end{array}$ & $\begin{array}{l}\text { Cellulase } \\
\text { (H/C) }\end{array}$ & $\begin{array}{l}\text { Protease } \\
\text { (H/C) }\end{array}$ & $\begin{array}{l}\text { Amylase } \\
\text { (H/C) }\end{array}$ & Lipase \\
\hline Aureobasidium pullulans Ach2-1 & 2.25 & ND & ND & 2.5 & ND & ND & ND \\
\hline Bacillus subtilis 2515-1 & 2.17 & 2.14 & 3.4 & 1.7 & 1.92 & 1.8 & ND \\
\hline Enterobacter ludwiqii 2546-4 & 2.25 & 1.87 & ND & 2.4 & 4 & ND & ND \\
\hline Acinetobacter calcoaceticus 2328-B5 & ND & ND & 0.62 & ND & 1.46 & ND & ND \\
\hline Rahnella aquatilis 2332-A & 2.7 & 2.2 & 15.06 & 2.5 & ND & ND & ND \\
\hline Bacillus cereus 2015-1 & 2.7 & 1.14 & ND & 3.1 & 2 & ND & ND \\
\hline Bacillus cereus 2021-2 & ND & 1.14 & ND & ND & 2.25 & ND & ND \\
\hline Acinetobacter calcoaceticus 2627-1 & ND & ND & ND & ND & 2.09 & ND & ND \\
\hline Pantoea agglomerans 2066-7 & ND & 2 & 6.58 & 2.4 & ND & ND & ND \\
\hline
\end{tabular}

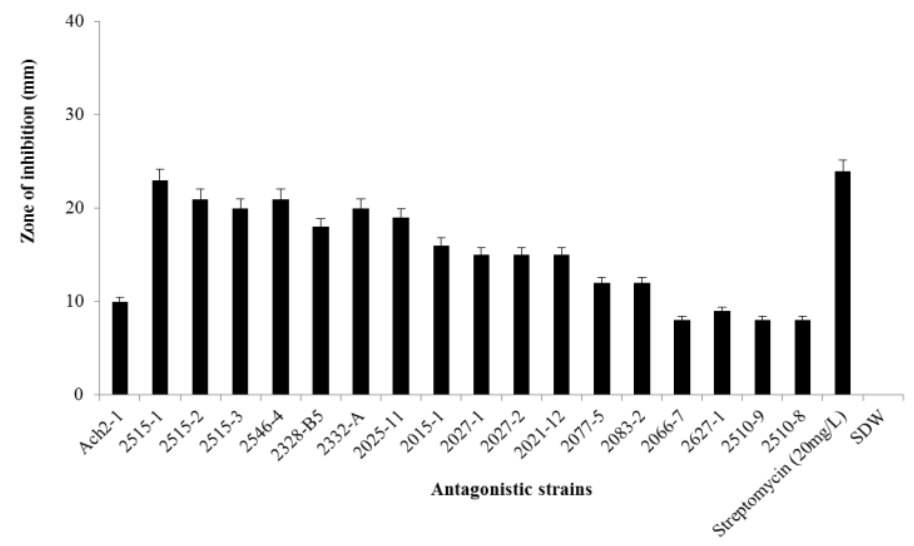

Figure 2 Histogram representing inhibition zone of the antagonistic strains tested in vitro against the Pseudomonas savastanoi pv. savastanoi 2102-4, positive control (streptomycin $20 \mathrm{mg} / \mathrm{L}$ ) and negative control (SDW).

Production of enzymes and secondary metabolites by antagonistic agents

Results presented in Tab $\mathbf{2}$ and Figure 3 showed that tested antagonistic bacteria produced all extracellular enzymes as well as siderophore and IAA metabolites. B. subtilis 2515-1 was able to release siderophores, soluble phosphorus, IAA, cellulase, protease, and amylase on specific media. Other bacteria, including $E$. ludwiqii (25464), A. calcoaceticus (2328-B5), P. agglomerans (2066-7) and B. cereus (2015-1) were only effective for production of some metabolites or enzymes. $R$. aquatilis (2332-A) was the most efficient strain with a higher siderophore index of 2.2 and IAA content $(15.06 \mu \mathrm{g} / \mathrm{ml})$. The highest index of phosphorus solubilization was detected from $R$. aquatilis $2332-\mathrm{A}$ and $B$. cereus 2021-2 (2.7). For cellulase activity, B. cereus 2015-1 was the most effective; its (index of 4.00). Finally, all bacterial strains did not show lipase activity. relative activity was 3.1 . E. ludwiqii $2546-4$ showed a highest activity of protease

ND: Not detectable; H/C: Halo zone diameter/colony diameter 


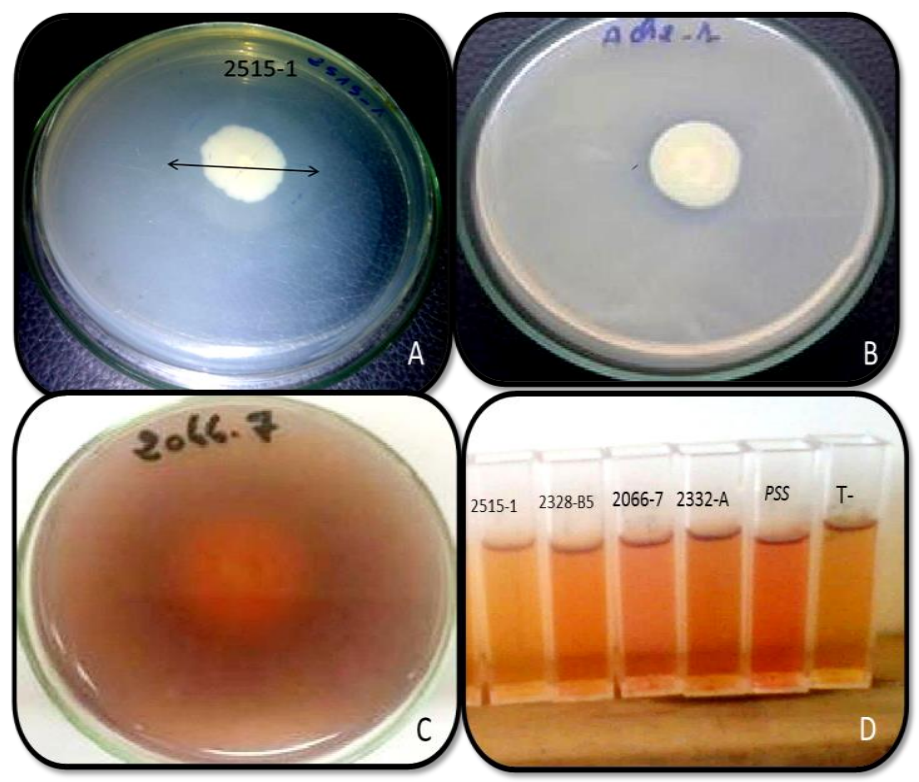

Figure 3 Halo diameter of enzymatic activities: A; amylase for Bacillus subtilis (2515-1), B; Phosphatase for A. Pullulans (Ach2-1), C; Cellulase for Pantoea agglomerans (2066-7) and D; Indole Acetic Acid production by all antagonistic strains.

PSS: 2064-8 pathogen strain alone

T -: negative control without bacterial stains

\section{In planta experiments}

The choice of B. subtilis $2515-1$ as biocontrol agent for in planta experiments was based on their ability to suppress the plant pathogens and produce effective enzymes involved in PSS control on solid media.

Sixty days after inoculation of trees with PSS 2064-8 and PSS 2102-4, typical knots appeared at the inoculated sites (Figure 4). These pathogen strains developed knots weighting between 0.66 to 0.85 and 0.49 to $0.70 \mathrm{~g}$ respectively. Inoculations with $B$. subtilis $2515-1$ have decreased the knot weight compared with copper sulphate as chemical treatment (Figure 5). Knot weight was reduced with $92.88 \%$ using B. subtilis strain $2515-1$ and only with $86.93 \%$ using copper sulphate against PSS 2064-8 (Figure 6). In the other hand, when the antagonistic 2515-1 strain was inoculated with pathogen strain of PSS 2102-4, knot weight reduction was only 50\% compared with copper sulphate (37. 5\%) (Figure 5).The highest reduction of knot weight was found by B. subtilis 2515-1 (95. 60\%) using pathogen strain PSS 2102-4 (Figure 6). Analysis of variance of the average weight of knots (Dunnett test) showed significant differences between antagonistic B. subtilis 2515-1 and infected plants (PSS 2102-4 or PSS 2064-8 without treatment). No significant differences were found between copper treatment and treatment with antagonistic B. subtilis 2515-1; their effectiveness was similar against pathogen strains (PSS 2102-4 or PSS 2064-8).
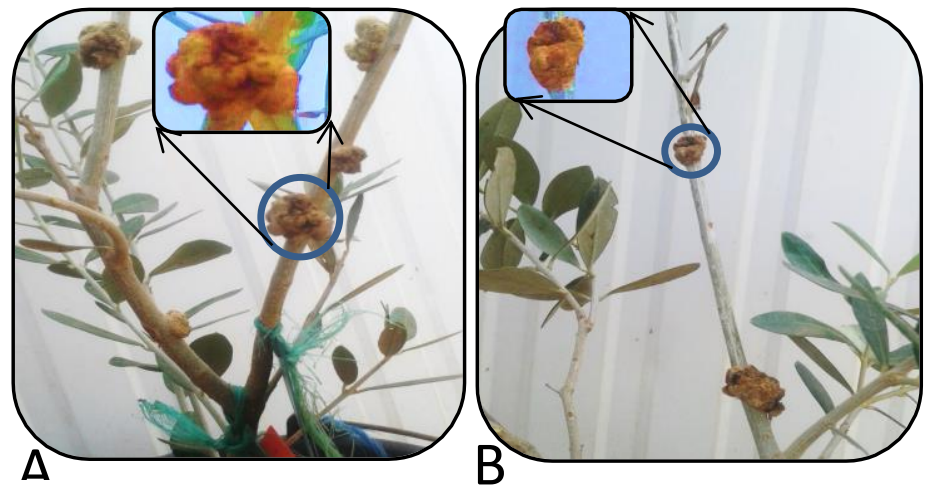

Figure 4 Reduction of weight and knot number after 60 days from inoculation with Bacillus subtilis 2515-1 on plants infected with Pseudomonas savastanoi pv. savastanoi 2102-4; (A) non-inoculated plant and (B) inoculated plant.
60

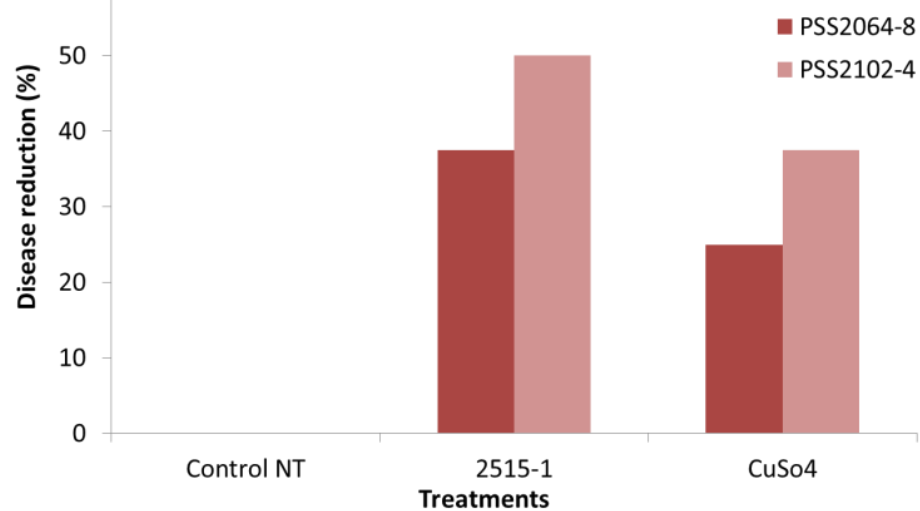

Figure 5 Disease reduction by Bacillus subtilis 2515-1 and copper sulphate $(0.5 \%)$ after inoculation with Pseudomonas savastanoi pv. savastanoi (PSS 2064-8 or PSS 2102-4).

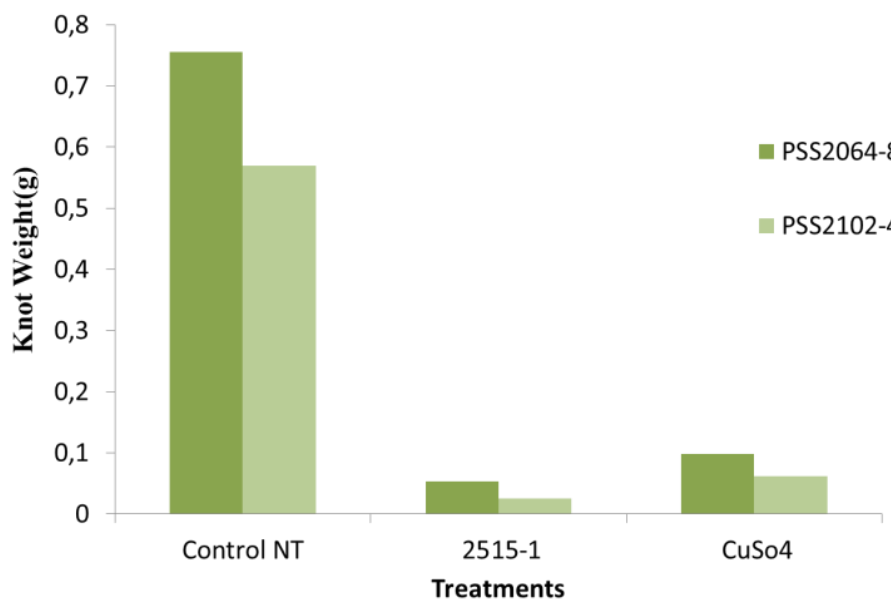

Figure 6 Effect of Bacillus subtilis strain 2515-1 and copper sulphate (0.5\%) on knot weight after inoculation with Pseudomonas savastanoi pv. savastanoi (PSS 2064-8 or PSS $2102-4$ ).

In vitro experiments showed that $B$. subtilis 2515-1, 2515-2 and 2515-3 strain, E. ludwiqii 2546-4 and $R$. aquatilis 2332-A strains were the most effective against PSS 2102-4. However, in planta experiment has shown that B. subtilis 2515-1 was the most efficient strain to reduce knot number and knot weight significantly. The control of PSS is exclusively based on the limitation of the first infection, thus, there is no effective measures exist for a strict control of this pathogen. Nevertheless, in the recent years, promoting results were obtained by using microbial antagonists effective in vitro (Lavermicocca et al., 2002; Rokni Zadeh et al., 2008; Kacem et al., 2009; Krid et al., 2010). Krid et al., (2010, 2012) studied the effect of two B. subtilis strains toward PSS and found that they formed an inhibition zone ranging from 12 to $25 \mathrm{~mm}$ of diameter depend the method of co-inoculation. El Hassni et al., (2007) showed that B. pumilus, $R$. aquatilis $B$. cereus had exhibited a high inhibition toward mycelial growth of Fusarium oxysporum f.sp albedinis (70-77\%), and its sporulation. It was reported that $R$. aquatilis was also effective to control crown gall in grape vine caused by Agrobacterium vitis strains (Chen et al., 2007; Habbadi et al., 2017) Indeed, siderophores produced by a microorganism can bind iron with high specificity and affinity, making the iron unavailable for pathogens, and thereby limiting their growth. This strategy may certainly be involved in the biological control of plant diseases (De Boer et al., 2003). Therefore, siderophoreproducing microorganisms may have promise as biological control agents. This approach of control can potentially help us to limit or reduce the use of chemical products that are harmful to the environment and health. Bacillus spp. were studied as biocontrol agents toward Fusarium wilt of tomato plants and showed its effectiveness in mycelial growth inhibition (46\%), siderophores (hydroxymate type) production, increasing of yield and crop protection (Ramyabharathi and Raguchander, 2014). R.aquatilis is known for its ability to produce IAA and solubilize complex phosphorus as previously reported (Ahemad and Kibret, 2014).

Moreover, B. subtilis produced a variety of extracellular enzymes including proteases, amylases and lipase of great importance in industrial processes, such as pharmaceutical, leather, laundry, food and waste processing industries (Schallmey et al., 2004). B. subtilis strains were also producers of cellulase that is of interest from the biotechnological point of view and in relation to the decomposition of agricultural residues remaining in the field after the crop is harvested (Singh and Hayashi, 1995). Furthermore, Bacillus spp. are well known as rhizosphere residents of many crops and usually show plant growth 
promoting activities that include biocontrol capacity against some diseases caused by fungi and bacteria, such as leaf spot of mustard caused by Alternaria brassicae (Sharma and Sharma, 2008), stem rot of soybean caused by Sclerotinia sclerotiorum (Zhang and Xue, 2010). Bacillus subtilis exhibited also a relatively high and specific antibacterial activity to bacterial pathogens such as Agro bacterium tumefaciens, Clavibacter michiganense subsp. michiganense, Pseudomonas syringae pv. syringae, Xanthomonas campestris pv.vesicator (Krebs et al., 1998; Rhouma et al., 2008). In general the Numerous studies have been done on genus Bacillus are among the most commonly reported as biocontrol and plant-growth promoting rhizobacteria are a group of beneficia bacteria that influence the growth (Huang et al., 2016), yield (Liu et al., 2016) and nutrient uptake of plants (Calvo et al., 2017), and that often exhibit biological control of plant disease (Xiang et al., 2017). Sustainable agriculture need exclusively the availability of alternative strategies of protection, and consequently, the development of environment-friendly and food-hygienicallysafe plant-protecting methods based on biological agents has been greatly emphasized (Warrior, 2000)

\section{CONCLUSION AND PERSPECTIVES}

B. subtilis strain 2515-1 appeared to be a promising biocontrol agent against PSS causal agent of olive knot. Also; this strain could be further exploited both as a biofertilizers and an effective biocontrol agent. Future studies should be focused on the involvement of this strain in field in a nursery naturally contaminated by olive knot disease to assess its effectiveness.

Acknowledgements: This work was supported by the funds of National Institute of Agronomic Research Meknes, Morocco.

\section{REFERENCES}

AHEMAD, M., KIBRET, M. 2014. Mechanisms and applications of plant growth promoting rhizobacteria: current perspective. Journal of King Saud UniversityScience, 26(1), 1-20. https://doi.org/10.1016/j.jksus.2013.05.001

BOUAICHI, A., BENKIRANE, R., AMEUR A., SADIK, S., BENBOUAZZA, A., ACHBANI, E.H. 2015. Characterization of Pantoea agglomerans Strains Isolated from Olive Knot disease in Morocco. Biolife, 3(2), 533-539. http://dx.doi.org/10.17812/blj2015.32.27

BOUDYACH, E. H., FATMI, M., AKHAYAT, O., BENIZRI, E., AOUMAR, A 2001. Selection of antagonistic bacteria of Clavibacter michiganensis subsp. michiganensis and evaluation of their efficiency against bacterial canker of tomato. Biocontrol Science and Technology, 11(1), 141-149. https://doi.org/10.1080/09583150020029817

CALVO, P., WATTS, D. B., KLOEPPER, J. W., TORBERT, H. A. 2017. Effect of microbial-based inoculants on nutrient concentrations and early root morphology of corn (Zea mays). Journal of Plant Nutrition and Soil Science, 180(1), 56-70. https://doi.org/10.1002/jpln.201500616

CHEN, F., GUO, Y. B., WANG, J. H., LI, J. Y., WANG, H. M. 2007. Biological control of grape crown gall by Rahnella aquatilis HX2. Plant disease, 91(8), 957-963. https://doi.org/10.1094/PDIS-91-8-0957

DE BOER, M., BOM, P., KINDT, F., KEURENTJES, J. J., VAN DER SLUIS, I., VAN LOON, L. C., BAKKER, P. A. 2003. Control of Fusarium wilt of radish by combining Pseudomonas putida strains that have different disease-suppressive mechanisms. Phytopathology, 93(5),

626-632 https://doi.org/10.1094/PHYTO.2003.93.5.626

EL HASSNI, M., EL HADRAMI, A., DAAYF, F., CHÉRIF, M., BARKA, E. A., EL HADRAMI, I. 2007. Biological control of bayoud disease in date palm: Selection of microorganisms inhibiting the causal agent and inducing defense reactions. Environmental and Experimental Botany, 59(2), 224-234. https://doi.org/10.1016/j.envexpbot.2005.12.008

EL KINANY, S., HAGGOUD, A., BENBOUAZA, A., BOUAICHI, A., ACHBANI, EL. 2017. Plant growth promotion and bacterial canker control of Lycopersicon esculentum L. cv. Campbell 33 by biocontrol agents. Journal of Crop Protection 6(2), 235-244. http://journals.modares.ac.ir/article-3-4806en.html

FERNANDES, A., MARCELO, M. 2000. A possible synergistic effect of Erwinia sp on the development of olive knot symptoms caused by Pseudomonas syringae pv. savastanoi in Olea europea. Acta Horticulturae 58(6), 729-731.

GODENA, S., DMINIĆ, I. ĐERMIC, E. 2012. Differential susceptibility of olive varieties to olive knot disease in Istria. JOURNAL OF CENTRAL EUROPEAN AGRICULTURE, 13(1), 85-94. https://doi.org/10.5513/JCEA01/13.1.1018

HABBADI, K., BENKIRANE, R., BENBOUAZZA, A., BOUAICHI, A., MAAFA, I., CHAPULLIOT, D., ACHBANI E. 2017. Biological Control of Grapevine Crown Gall Caused by Allorhizobium vitis using Bacterial Antagonists. International Journal of Science and Research, 6(6), 1390-1397. ISSN: 2319-7064

$$
\text { https://doi.org/10.17660/ActaHortic.2002.586.156 }
$$

HUANG, P., DE-BASHAN, L., CROCKER, T., KLOEPPER, J. W., BASHAN, Y. 2016. Evidence that fresh weight measurement is imprecise for reporting the effect of plant growth-promoting (rhizo) bacteria on growth promotion of crop plants. Biology and Fertility of Soils 53(2), 199-208. https://doi.org/10.1007/s00374-016-1160-2

KACEM, M., KAZOUZ, F., MERABET, C., REZKI, M., DE LAJUDIE, P. BEKKI, A. 2009. Antimicrobial activities of Rhizobium sp. strains against Pseudomonas savastanoi, the agent responsible for the olive knot disease in Algeria .Grasas Y Aceites, 60(2), 139-146. DOI: 10.3989/gya.074808

KING, E.O., WARD, M.K. RANEY, D. E. 1954. Two simple media for the demonstration of pyocyanin and fluorescein. Journal of Laboratory and Clinical Medicine, 44(2), 301-307.

KREBS, B., HÖDING, B., KÜBART, S., WORKIE, M. A., JUNGE, H., SCHMIEDEKNECHT, G HEVESI, M. 1998. Use of Bacillus subtilis as biocontrol agent. I. Activities and characterization of Bacillus subtilis strains. Journal of Plant Diseases and Protection, 105(2), 181-197. https://www.jstor.org/stable/43215232

KRID, S., RHOUMA, A., MOGOU, I., QUESADA, J.M., NESME, X., GARGOURI, A. 2010. Pseudomonas savastanoi endophytic bacteria in olive tree knots and antagonistic potential of strains of Pseudomonas fluorescens and Bacillus subtilis. Journal of Plant Pathology, 92(2), 335-341. https://www.jstor.org/stable/41998806

KRID, S., TRIKI, M. A., GARGOURI, A., RHOUMA, A. 2012. Biocontrol of olive knot disease by Bacillus subtilis isolated from olive leaves. Annals of microbiology, 62(1):149-154. https://doi.org/10.1007/s13213-011-0239-0

LAVERMICOCCA, P., LONIGRO, S.L., VALERIO, F., EVIDENTE, A VISCONTI, A. 2002. Reduction of olive knot disease by a bacteriocin from Pseudomonas syringae pv. ciccaronei. Applied and Environmental Microbiology, 68(3), 1403-1407. DOI: 10.1128/AEM.68.3.1403-1407.2002

LIN, L., MENG, X., LIU, P., HONG, Y., WU, G., HUANG, X., LI, C., DONG, J., XIAO, L. LIU, Z. 2009. Improved catalytic efficiency of Endo- $\beta-1,4$ glucanase from Bacillus subtilis BME-15 by directed evolution. Applied $\begin{array}{llll}\text { Microbiology and Biotechnology, 82(4), 671-679. } & \text {. }\end{array}$ https://doi.org/10.1007/s00253-008-1789-3

LIU, K., GARRETT, C., FADAMIRO, H., KLOEPPER, J. W. 2016. Induction of systemic resistance in Chinese cabbage against black rot by plant growthpromoting rhizobacteria. Biological control 99, 8-13. https://doi.org/10.1016/j.biocontrol.2016.04.007

MARCHI, G., SISTO, A., CIMMINO, A., ANDOLFI, A., CIPRIANI, M.G., EVIDENTE, A., SURICO, G. 2006. Interaction between Pseudomonas savastanoi pv. savastanoi and Pantoea agglomerans in olive knots. Plant Pathology, 55(5), 614- 624. https://doi.org/10.1111/j.1365-3059.2006.01449.x

MERCIER, J., LINDOW, S.E. 2001. Field performance of antagonistic bacteria identified in a novel blight of pear. Biological Control, 22(1), 66-71. https://doi.org/10.1006/bcon.2001.0957

PIKOVSKAYA, RI. 1948. Mobilization of $\mathrm{P}$ in soil in connection with vita activity by some microbial species. Microbiologica, 17, 362-370. ISSN; 02168170

PREMONO, M.E., MOAWAD, A.M. AND VLEK PLG. 1996. Effect of phosphorus-solubilizing Pseudomonas putida on the growth of maize and its survival in the rhizosphere. Indonesian journal of crop science, 11(1), 13-23. ISSN: 0216-8170

RAMYABHARATHI, S.A., RAGUCHANDER, T. 2014. Mode of action of bacillus subtilis EPCO16 against tomato fusarium wilt. Biochemical and Cellular Archives, 14(1), 47-50. ISSN 0972-5075.

RHOUMA, A., BOURI, M., BOUBAKER, A., NESME, X. 2008. Potential effect of rhizobacteria in the management of crown gall disease caused by Agrobacterium tumefaciens biovar1. Journal of Plant Pathology, 90(3), 517-526. https://www.jstor.org/stable/41998547

ROKNI ZADEH, H., KHAVAZI, K., ASGHARZADEH, A., HOSSEINIMAZINANI, M. DE MOT R. 2008. Biocontrol of Pseudomonas savastanoi, Causative agent of olive knot disease: antagonistic potential of non-pathogenic rhizosphere isolates of fluorescent Pseudomonas. Communications in agricultural and applied biological sciences journal, 73(1), 199-203. ISSN: 1379-1176.

SADIK, S., MAZOUZ, H., BENBOUAZZA, A., ACHBANI, E. H. 2016. Ecology of Pantoea agglomerans 2066-7 strain: a biological control of bacteria onion diseases. The Journal of Microbiology, Biotechnology and Food Sciences, 5(6), 612. https://doi.org/10.15414/jmbfs.2016.5.6.612-616

SCHALLMEY, M.; SINGH, A. WARD, O.P. 2004. Development in the use of Bacillus species for industrial production. Can Journal Microbiol, 50(1), 1-17. https://doi.org/10.1139/w03-076

SCHWYN, B., NEILANDS, J.B. 1987. Universal chemical assay for the detection and determination of siderophores. Analytical biochemistry, 160(1), 46-56. https://doi.org/10.1016/0003-2697(87)90612-9

SHARMA, B., SINGH, M. 2015. Isolation and characterization of bacteria from cow dung of desi cow breed on different morpho-biochemical parameters in Dehradun, Uttarakhand, India. International journal of advances in pharmacy, biology and chemistry, 4(2), 276-281. ISSN: 2277-4688

SHARMA, N., SHARMA, S. 2008. Control of foliar diseases of mustard by Bacillus from reclaimed soil. Microbiological Research, 163(4), 408-413. https://doi.org/10.1016/j.micres.2006.06.011 
SINGH, A, HAYASHI, K. 1995. Microbial cellulases: proteinarchi- tecture, molecular properties and biosynthesis. ADVANCES IN APPLIED MICROBIOLOGY, 40, 1-44. https://doi.org/10.1016/S0065-2164(08)70362-9 SISTO, A., CIPRIANI, M.G. MOREA, M. 2004. Knot formation caused by Pseudomonas syringae subsp. savastanoi on olives is hrp-dependent Phytopathology, 94(5), 484-489. https://doi.org/10.1094/PHYTO.2004.94.5.484 SURICO, G., IACOBELLIS, N.S. SISTO, A. 1985. Studies on the role of indole-3-acetic acid and cytokinins in the formation of knots on olive and oleander plants by Pseudomonas syringae pv. savastanoi. Physiological Plant Pathology, 26(3), 309-320. https://doi.org/10.1016/0048-4059(85)90006-2

TROTEL-AZIZ, P., COUDERCHET, M., BIAGIANTI, S. AZIZ, A. 2008 Characterization of new bacterial biocontrol agents Acinetobacter, Bacillus, Pantoea and Pseudomonas spp. Mediating grapevine resistance against Botrytis cinerea. Environmental And Experimental Botany, 64(1), 21-32. https://doi.org/10.1016/j.envexpbot.2007.12.009

TSAVKELOVA, E.A., CHERDYNTSEVA, T.A., BOTINA, S.G. NETRUSOV, A.I. 2007. Bacteria associated with orchid roots and microbial production of auxin. Microbiological Research, 162(1), 69-76. https://doi.org/10.1016/j.micres.2006.07.014

VAN DEN BROEK, D., CHIN-A-WOENG, T.F.C., EIJKEMANS, K. MULDERS, I.H.M., BLOEMBERG, G.V. LUGTENBERG, B.J.J. 2003 Biocontrol traits of Pseudomonas spp. are regulated by phase variation. Molecular Plant Microbe Interaction, 16(11), 1003-1012. https://doi.org/10.1094/MPMI.2003.16.11.1003

WARRIOR, P. 2000. Living system as natural crop-protection agents. Pest Management Science, 56(8), 681-687. https://doi.org/10.1002/15264998(200008)56:8\%3C681::AID-PS199\%3E3.0.CO;2-S

XIANG, N., LAWRENCE, K. S., KLOEPPER, J. W., DONALD, P. A. MCINROY, J. A., LAWRENCE, G. W. 2017. Biological control of Meloidogyne incognita by spore forming plant growth promoting rhizobacteria on cotton. Plant Disease. 101(5), 774-784. https://doi.org/10.1094/PDIS-09-16-1369-RE

YOUNG, J.M.2004. Olive knot and its pathogens. Australian Plant Pathology, 33(1), 33-39. https://citations.springer.com/item?doi=10.1071/AP03074

ZHANG, J.X., XUE, A.G. 2010. Biocontrol of sclerotinia stem rot (Sclerotinia sclerotiorum) of soybean using novel Bacillus subtilis strain SB24 under control conditions. Plant Pathology Journal, 59(2), 382-391. https://doi.org/10.1111/j.1365-3059.2009.02227.x 